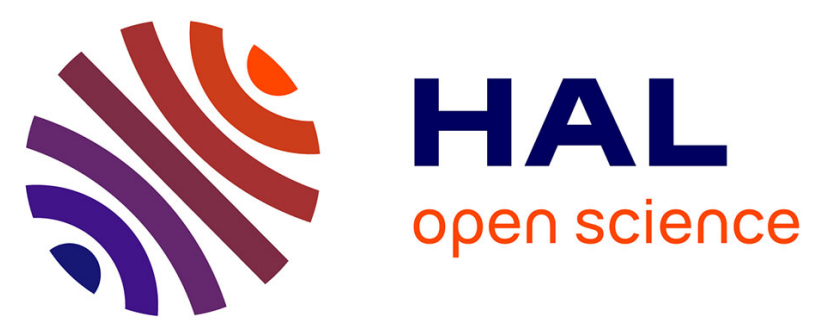

\title{
Endobronchial ultrasound-guided transbronchial needle aspiration is feasible, safe, and reaches a $90 \%$ diagnostic yield in patients with hypoxemic acute respiratory failure
}

Maxens Decavèle, Valérie Gounant, Jocelyne Fleury Feith, Michel Febvre, Jean-Marc Naccache, Antoine Parrot, Muriel Fartoukh

\section{To cite this version:}

Maxens Decavèle, Valérie Gounant, Jocelyne Fleury Feith, Michel Febvre, Jean-Marc Naccache, et al.. Endobronchial ultrasound-guided transbronchial needle aspiration is feasible, safe, and reaches a $90 \%$ diagnostic yield in patients with hypoxemic acute respiratory failure. Intensive Care Medicine, 2016, 42 (8), pp.1295-1298. 10.1007/s00134-016-4377-5 . hal-01319989

\section{HAL Id: hal-01319989 \\ https://hal.sorbonne-universite.fr/hal-01319989}

Submitted on 23 May 2016

HAL is a multi-disciplinary open access archive for the deposit and dissemination of scientific research documents, whether they are published or not. The documents may come from teaching and research institutions in France or abroad, or from public or private research centers.
L'archive ouverte pluridisciplinaire HAL, est destinée au dépôt et à la diffusion de documents scientifiques de niveau recherche, publiés ou non, émanant des établissements d'enseignement et de recherche français ou étrangers, des laboratoires publics ou privés. 
Endobronchial ultrasound-guided transbronchial needle aspiration is feasible, safe and reach a $90 \%$ diagnostic yield in patients with hypoxemic acute respiratory failure

M Decavèle, V Gounant, J Fleury-Feith, M Febvre, JM Naccache, A Parrot, M Fartoukh.

Online Supplement (with 1 Table and 2 figures)

\section{Patients and methods}

\section{Selection of the patients}

Patients were selected from a prospective cohort [1] that comprehensively describes all EBUS-TBNA procedures performed in Tenon hospital, a tertiary university teaching hospital in Paris, France. Over the study period (May 2011-May 2015), the database comprised 842 records almost exclusively performed in the respiratory department, a referral center for lung cancer. Of those latter, 9 were performed in the ICU.

\section{Methods and Sampling Procedures}

EBUS-TBNA equipment was a $6.7 \mathrm{~mm}$ outer diameter, real-time, bronchoscope (BF-UC160F; Olympus Ltd., Tokyo, Japan) with a 7.5-MHz linear ultrasound transducer set on a 50 $\mathrm{mm}$ maximal penetration. Specimens were obtained using a 22-gauge dedicated needle (Figure 1) equipped with a stylet (ViziShot NA-201SX; Olympus Ltd). EBUS-TBNA was performed by three interventional pulmonologists (V.G., M.F., JM.N.), whereas ROSE was performed by a single experienced lung cytologist (J.F.). The diagnosis obtained with EBUSTBNA was based on cytological material examination; all specimens were reviewed by J.F. The representative nature of the aspirations was established by the presence of characteristic lymph node cells [2]. Only when representative, cytological samples were either positive if they carried a diagnosis, or negative if only lymphocytes were observed. The final diagnosis was based on EBUS-TBNA samples and all other diagnostic procedures.

Because of its large diameter, the bronchoscope was inserted either orally or through the endotracheal tube, whether the patients were breathing spontaneously or mechanically 
ventilated. EBUS was performed under conscious sedation (mild sedation) or general anesthesia [3]. As recommended, local anesthesia (2\% lidocaine) was systematically administered to further minimize cough [4]. Mild sedation included hydroxyzine, bolus of midazolam or propofol with domperidone and atropine.

\section{Statistical analysis and ethical considerations}

Demographics, clinical variables, and laboratory findings are reported as median (interquartile range) and the absolute and relative frequencies are used for categorical variables, unless stated otherwise. Statistical analysis was performed with Stata 10.1 software (StataCorp, College Station, Texas).

The samples were collected according to French legislation and the ethical rules of our institution at the time the experiments were carried out. All patients or relatives were informed and gave consent

\section{Results}

\section{Patient's characteristics}

During the study period, 9 patients (8 males; age 62 years [18-42]; IGS2 22 [18-42]) underwent an EBUS-TBNA procedure, 5 [2-8] days after ICU admission. Table 2 displays the patients' characteristics during the procedure. The reasons for ICU admission were acute respiratory failure $(\mathrm{ARF}, \mathrm{n}=5)$, asphyxiating hemoptysis $(\mathrm{n}=1)$ and abundant hemoptysis ( $\mathrm{n}=3$, including 2 hemoptysis after bronchial biopsy). The median SOFA score was 2 [2-4] and vasopressors were ongoing for 2 patients (22\%) on the day of EBUS-TBNA.

\section{Radiological findings}

All patients had undergone a median of 2 [1-3] CT-scan before EBUS was performed. The CT scan patterns were reviewed by V.G. Lung or pleura were involved in all patients. 
Mediastinal and hilar lymphadenopathy were observed in 8 patients, whereas an isolated mediastinal lymphadenopathy was observed in the remaining (patient 4). The size of lymph nodes punctured ranged between 5 and $35 \mathrm{~mm}$. Noteworthy, a fluorine-18fludeoxyglucose (18F-FDG) positron emission tomography (PET)/CT had been performed in 4 patients within the preceding 30 days, demonstrating at least one hypermetabolic lymph node with a maximal standardized uptake value (SUVmax) ranging from 3.7 to 8.5 .

\section{Prior diagnosis procedures and rationale for EBUS-TBNA recourse}

Bronchoscopic lower respiratory tract samplings (tracheal aspirate TA, or bronchoalveolar lavage BAL) were obtained in all patients for usual pathogens and mycobacteria. Three patients had a positive bacterial culture (Enterococcus faecalis, $\mathrm{n}=1$; Proteus mirabilis, $\mathrm{n}=1$; Serratia marcescens, $\mathrm{n}=1$ ), and all were negative for mycobacteria. In addition to conventional lung sampling procedures, other tissue samples were obtained before EBUSTBNA was performed, including gastroduodenal $(n=3)$, skin $(n=3)$, or accessory salivary gland $(n=1)$ biopsies, and thyroid fine needle aspiration $(n=1)$. In addition to life-threatening hemoptysis complicating lung biopsies (patients $2,4,6,7$ ), the severity of the underlying pulmonary disease (patients 1,5 and 8 ) and the accessibility to the paratracheal region (patient 9) also participated to the intensivists' decision for performing EBUS.

\section{Diagnosis accuracy and safety of EBUS-TBNA}

Excluding the patient 6 for whom all aspirations were non-representative of the node structure, EBUS-TBNA was representative of lymph node structure in $69 \%$ of the cases (41 of 59 aspirations). When necessary, molecular testing was performed on EBUS-TBNA samples (patients 4 and 9). Strikingly, central pulmonary embolism was distinctly observed by EBUS in one patient (patient 4).

There were no complications, except minor bleedings at the puncture site (patients 7 and 9) that were merely controlled by local instillation of cold serum or adrenaline. 


\section{Discussion}

If the role of EBUS-TBNA or esophageal ultrasound-guided fine needle aspiration (EUSFNA) has been traditionally limited to non emergent settings, its expanding applications and performances may concern intensivists, regarding the recent reports of esophageal EUS-FNA in critically ill patients [5-7].

\section{Safety}

The safety of EBUS/EUS-FNA has been widely assessed in large series [8, 9], complications being very rarely reported [10-13]. In a recent prospective quality improvement registry [9] enrolling more than 1300 non-critically ill patients undergoing EBUS-TBNA, the rate of complications was $1.4 \%$, including pneumothorax $(n=7 ; 0.5 \%)$, sustained hypoxemia $(n=4$; $0.3 \%)$, bleeding $(n=3 ; 0.2 \%)$ and respiratory failure $(n=3 ; 0.2 \%)$. In multivariate analysis, TBLB performed during the procedure was the only factor associated with the occurrence of pneumothorax. However, complications (especially pneumothorax) of TBLB may average $15 \%$ in critically ill cancer or mechanically ventilated patients $[14,15]$ when performed during fiberoptic bronchoscopy. Similarly, the complications related to CT-guided biopsy are frequent and may be fatal [16, 17]. Finally, open lung biopsy (OLB) exhibits very high complications rates ranging from 20 to $56 \%$, when performed in mechanically ventilated patients with undiagnosed diffuse pulmonary infiltrates [18, 19]. Altogether, the side effects of TBLB, CT-guided or OLB should be confronted to the vulnerability of critically ill patients, particularly hematological patients [20].

In our series, EBUS-TBNA was a diagnostic technique of particular value in selected patients (patients 2, 4, 6 and 7) who were estimated to be at high risk of bleeding during conventional lung sampling procedures. In particular, for the patients 3 and 7, the real time visualization of a vessel through the lymph node (station 4 and 7, respectively) prompted the operator to avoid 
the vessel during the puncture or to puncture another lymph node. In the same way, EBUSTBNA was also a precious alternative diagnostic procedure in patients suffering of severe respiratory insufficiency (patients 1, 3 and 5) in whom the occurrence of a pneumothorax was feared.

\section{Diagnostic yield}

In our series, the diagnostic yield of EBUS-TBNA was higher than that reported with conventional lung samples procedures in critically ill patients, especially TBLB either isolated or combined with BAL [14, 21, 22], or CT-guided mediastinal biopsy [23]. Finally, EBUSTBNA yield approached that of open lung biopsy in mechanically ventilated patients [18].

Even if such information may be interpreted with caution [24], ROSE may certainly have participated to the high diagnostic rate, by improving the quality of the samples $[1,24,25]$. Moreover, EBUS demonstrated exceptional accuracy in some cases of diagnostic deadlock (patient 3), by providing the diagnosis of angiosarcoma, without any worsening of the critical respiratory state.

\section{Feasibility}

Endotracheal tube placement or laryngeal mask may be useful to perform EBUS-TBNA under general anesthesia (GA). Passing the EBUS scope is roughly equivalent to passing a standard fiberoptic bronchoscope except that, depending on the diameter, it may significantly impact on pressures and volumes. If passed through a $\$ 8.5$ endotracheal tube, EBUS occludes $66 \%$ of the cross-section. The occlusion reaches $74 \%$ and $80 \%$ for $\sharp 8$ and $\sharp 7.5$ tubes, respectively. In patient 6 , kink or secretions may have completed the tube obstruction that constrained the operator to remove intermittently the EBUS scope to allow mechanical ventilation. So, we recommend at least a $\# 8$ tube. No ventilatory complications were reported with the $\$ 8.5$ endotracheal tube or the laryngeal mask. 
A second limitation resides in the fact that lymph node stations 5, 6, 8 and 9 are not accessible by EBUS approach for anatomical reasons (Figure 2). In addition, the diameter of the scope prevents the access to the station 14. However the access to the areas 5, 6,8 and 9 can be recovered by associating an esophageal ultrasound-guided (EUS) phase likewise approved as a safe procedure [26].

Finally, the extent of sedation (minimal, moderate, deep, GA) for the procedure is not specifically defined, and may depend on the duration and the complexity of the procedure as well as the tolerance of the patient [4]. A target-controlled infusion of sedation may bring particular benefits (patient 9) by reducing the hemodynamics side effects of the sedation [27] and should be evaluated.

To summarize, advances in ultrasound technology enhance the area of diagnostic applications in daily clinical practice. In the ICU setting, EBUS-TBNA is a safe procedure, associated with a good and rapid diagnosis yield at bedside, so that it might be preferable to TBLB, when the hilum and/or mediastinum are involved. Finally, EBUS-TBNA appears as an elegant diagnostic solution with minimal risks in vulnerable patients. Further studies are needed to confirm these promising results.

\section{References of the online supplement}

1. Gounant V, Fleury-Feith J. Endobronchial ultrasound-guided transbronchial needle aspiration (EBUS-TBNA) (2012) Experience of Tenon hospital (HU Est parisien, AP-HP Paris). The point of view of the pneumologist, the point of view of the cytologist. Ann Pathol 32:84-8

2. Herth FJ, Annema JT, Eberhardt R, Yasufuku K, Ernst A, Krasnik M, Rintoul RC (2008). Endobronchial ultrasound with transbronchial needle aspiration for restaging the mediastinum in lung cancer. J Clin Oncol 26:3346-50

3. Casal RF, Lazarus DR, Kuhl K, Nogueras-González G, Perusich S, Green LK, Ost DE, Sarkiss M, Jimenez CA, Eapen GA, Morice RC, Cornwell L, Austria S, Sharafkanneh A, Rumbaut RE, Grosu H, Kheradmand F (2015) Randomized trial of endobronchial ultrasoundguided transbronchial needle aspiration under general anesthesia versus moderate sedation. Am J Respir Crit Care Med 191:796-803 
4. Wahidi MM, Jain P, Jantz M, Lee P, Mackensen GB, Barbour SY, Lamb C, Silvestri GA (2011) American College of Chest Physicians consensus statement on the use of topical anesthesia, analgesia, and sedation during flexible bronchoscopy in adult patients. Chest 140:1342-50

5. Fritscher-Ravens A, Sriram PV, Pothman WP, Füllekrug B, Jäckle S, Thonke F, Soehendra N (2000) Bedside endosonography and endosonography-guided fine-needle aspiration in critically ill patients: a way out of the deadlock? Endoscopy 32:425-7

6. Berzosa M, Davies SF, Gupta K, Debol SM, Li R, Miranda D, Mallery S (2013) Diagnostic bedside EUS in the intensive care unit: a single-center experience. Gastrointest Endosc 77:200-8

7. Bhaskar N, Shweihat YR, Bartter T (2014) The intubated patient with mediastinal disease-a role for esophageal access using the endobronchial ultrasound bronchoscope. J Intensive Care Med 29:43-6

8. Zhang R, Ying K, Shi L, Zhang L, Zhou L (2013) Combined endobronchial and endoscopic ultrasound-guided fine needle aspiration for mediastinal lymph node staging of lung cancer: a meta-analysis. Eur J Cancer 49:1860-1867

9. Eapen GA, Shah AM, Lei X, Jimenez CA, Morice RC, Yarmus L, Filner J, Ray C, Michaud G, Greenhill SR, Sarkiss M, Casal R, Rice D, Ost DE (2013) American College of Chest Physicians Quality Improvement Registry, Education. Complications, consequences, and practice patterns of endobronchial ultrasound-guided transbronchial needle aspiration: Results of the AQuIRE registry. Chest 143:1044-53

10. Huang CT, Chen CY, Ho CC, Yu CJ (2011) A rare constellation of empyema, lung abscess, and mediastinal abscess as a complication of endobronchial ultrasound-guided transbronchial needle aspiration. Eur J Cardiothorac Surg 40:264-5

11. Steinfort DP, Johnson DF, Irving LB (2010) Incidence of bacteraemia following endobronchial ultrasound-guided transbronchial needle aspiration. Eur Respir J 36:28-32

12. Botana-Rial M, Núñez-Delgado M, Pallarés-Sanmartín A, Leiro-Fernández V, Represas Represas C, González Silva AI, Fernández-Villar A (2012) Intramural hematoma of the pulmonary artery and hemopneumomediastinum after endobronchial ultrasound-guided transbronchial needle aspiration. Respiration 83:353-6

13. Özgül MA, Çetinkaya E, Tutar N, Özgül G (2014) An unusual complication of endobronchial ultrasound-guided transbronchial needle aspiration (EBUS-TBNA): the needle breakage. Ann Thorac Cardiovasc Surg 20:567-9

14. O'Brien JD, Ettinger NA, Shevlin D, Kollef MH (1997) Safety and yield of transbronchial biopsy in mechanically ventilated patients. Crit Care Med. 1997 25:440-6

15. Yoo H, Suh GY, Jeong BH, Lim SY, Chung MP, Kwon OJ, Jeon K (2013) Etiologies, diagnostic strategies, and outcomes of diffuse pulmonary infiltrates causing acute respiratory failure in cancer patients: a retrospective observational study. Crit Care 23:R150

16. de Margerie-Mellon C, de Bazelaire C, Amorim S, Brice P, Tazi A, Brière J, Frija J, de Kerviler E (2015) Diagnostic Yield and Safety of Computed Tomography-guided Mediastinal Core Needle Biopsies. J Thorac Imaging 30:319-27

17. Nour-Eldin NE, Alsubhi M, Naguib NN, Lehnert T, Emam A, Beeres M, Bodelle B, Koitka K, Vogl TJ, Jacobi V (2014) Risk factor analysis of pulmonary hemorrhage complicating CT-guided lung biopsy in coaxial and non-coaxial core biopsy techniques in 650 patients. Eur J Radiol 83:1945-52

18. Libby LJ, Gelbman BD, Altorki NK, Christos PJ, Libby DM (2014) Surgical lung biopsy in adult respiratory distress syndrome: a meta-analysis. Ann Thorac Surg 98:1254-60

19. Lim SY, Suh GY, Choi JC, Koh WJ, Lim SY, Han J, Lee KS, Shim YM, Chung MP, Kim H, Kwon OJ (2007) Usefulness of open lung biopsy in mechanically ventilated patients with 
undiagnosed diffuse pulmonary infiltrates: influence of comorbidities and organ dysfunction. Crit Care 11:R93

20. Levi M, Opal SM (2006) Coagulation abnormalities in critically ill patients. Crit Care 10:222

21. Rao VK, Ritter J, Kollef MH (1998) Utility of transbronchial biopsy in patients with acute respiratory failure: a postmortem study. Chest 114:549-55

22. Bulpa PA, Dive AM, Mertens L, Delos MA, Jamart J, Evrard PA, Gonzalez MR, Installé

EJ (2003) Combined bronchoalveolar lavage and transbronchial lung biopsy: safety and yield in ventilated patients. Eur Respir J 21:489-94

23. Gay J, Lemiale V, Meignin V, Bron C, De Bazelaire C, Schnell D, Canet E, Seguin A, Azoulay E (2013) Diagnostic contribution from pulmonary biopsies in hematology patients with acute respiratory failure from undetermined etiology. Minerva Anestesiol 79:853-60.

24. Nakajima T, Yasufuku K, Saegusa F, Fujiwara T, Sakairi Y, Hiroshima K, Nakatani Y, Yoshino I (2013) Rapid on-site cytologic evaluation during endobronchial ultrasound-guided transbronchial needle aspiration for nodal staging in patients with lung cancer. Ann Thorac Surg 95:1695-9

25. Kumar S, Chandra S (2014) A "ROSE" in every "EBUS" keeps transbronchial lung biopsy away. Chest 146:e97

26. Micames CG, McCrory DC, Pavey DA, Jowell PS, Gress FG (2007) Endoscopic ultrasound-guided fine-needle aspiration for non-small cell lung cancer staging: A systematic review and meta-analysis. Chest 131:539-48

27. Chalumeau-Lemoine L, Stoclin A, Billard V, Laplanche A, Raynard B, Blot F (2013) Flexible fiberoptic bronchoscopy and remifentanil target-controlled infusion in ICU: a preliminary study. Intensive Care Med 39:53-8

28. Moutain CF, Dresler CM (1997) Regional lymph node classification for lung cancer staging. Chest 111:1718-172

29. Rusch VW, Asamura H, Watanabe H, Giroux DJ, Rami-Porta R, Goldstraw P; Members of IASLC Staging Committee (2009) The IASLC lung cancer staging project: a proposal for a new international lymph node map in the forthcoming seventh edition of the TNM classification for lung cancer. J Thorac Oncol 4:568-77 


\section{Table of the Online Supplement}

Table 2. Diagnostic steps before EBUS-TBNA and patients' characteristics during procedure

\begin{tabular}{|c|c|c|c|c|c|c|c|c|c|c|c|c|c|c|c|c|}
\hline \multirow{2}{*}{$\begin{array}{c}\text { Patient } \\
\text { Gender/age }\end{array}$} & \multirow{2}{*}{$\begin{array}{l}\text { Respiratory } \\
\text { Support }\end{array}$} & \multicolumn{6}{|c|}{ Lung samples before EBUS, $n$} & \multirow{2}{*}{$\begin{array}{l}\text { Puncture } \\
\text { station }\end{array}$} & \multirow{2}{*}{$\begin{array}{l}\text { TEP } \\
\text { SUVm }\end{array}$} & \multirow{2}{*}{ Vasopressor } & \multirow{2}{*}{ Sedation } & \multirow{2}{*}{$\mathbf{P A}^{\mathbf{a}}$} & \multirow{2}{*}{$\begin{array}{c}\text { Heart } \\
\text { Rate } / \mathrm{min}\end{array}$} & \multirow{2}{*}{$\begin{array}{l}\text { Respiratory } \\
\text { Rate /min }\end{array}$} & \multirow{2}{*}{$\begin{array}{c}\mathrm{PaO}_{2} \\
\mathbf{m m H g}\end{array}$} & \multirow{2}{*}{$\begin{array}{l}\text { Duration } \\
\text { /min }\end{array}$} \\
\hline & & $B A$ & $B A L$ & $P P$ & $B B$ & $T T B$ & OTLB & & & & & & & & & \\
\hline $\begin{array}{l}\text { Patient } 1 \\
\mathrm{M} / 70\end{array}$ & $\begin{array}{l}\text { ET-MV/FiO } \mathbf{2}_{2}: \mathbf{0 . 6} \\
\text { VT: } 450 \mathrm{ml} \\
\text { PEEP: } 7 \mathrm{cmH}_{2} \mathrm{O}\end{array}$ & 1 & 1 & 1 & 2 & 1 & - & 7 & 3.7 & Norepinephrine & $\begin{array}{l}\text { General anesthesia } \\
\text { Midazolam } \\
\text { Sufentanil }\end{array}$ & No & 93 & 30 & $\begin{array}{c}150 \\
\mathrm{FiO}_{2}: 0.6\end{array}$ & 35 \\
\hline $\begin{array}{c}\text { Patient } 2 \\
\text { M/65 }\end{array}$ & $\begin{array}{l}\text { Nasal Oxygen } \\
41 / \mathrm{min}\end{array}$ & - & - & - & 1 & - & - & $\begin{array}{l}4 \mathrm{~L} \\
11 \mathrm{~L}\end{array}$ & - & No & $\begin{array}{l}\text { Mild sedation } \\
\text { Hydroxyzine }\end{array}$ & No & 77 & 16 & $\begin{array}{c}76 \\
\mathrm{O}_{2}: 41 / \mathrm{min}\end{array}$ & 25 \\
\hline $\begin{array}{c}\text { Patient } 3 \\
\text { F/35 }\end{array}$ & $\begin{array}{l}\text { Nasal Oxygen } \\
61 / \mathrm{min}\end{array}$ & 1 & 1 & 1 & - & - & 1 & $12 \mathrm{R}$ & 6.5 & No & $\begin{array}{l}\text { Mild sedation } \\
\text { Midazolam }\end{array}$ & No & 92 & 32 & $\begin{array}{c}75 \\
\mathrm{O}_{2}: 61 / \mathrm{min}\end{array}$ & 30 \\
\hline $\begin{array}{c}\text { Patient } 4 \\
\mathrm{M} / 34\end{array}$ & $\begin{array}{l}\text { Nasal Oxygen } \\
91 / \mathrm{min}\end{array}$ & - & - & - & 1 & - & - & $4 \mathrm{R}$ & 8.5 & No & $\begin{array}{l}\text { Mild sedation } \\
\text { Midazolam } \\
\text { Propofol }\end{array}$ & No & 96 & 30 & $\begin{array}{c}94 \\
\mathrm{O}_{2}: 9 \mathrm{l} / \mathrm{min}\end{array}$ & 25 \\
\hline $\begin{array}{c}\text { Patient } 5 \\
\text { M/64 }\end{array}$ & $\begin{array}{l}\text { Nasal Oxygen } \\
31 / \text { min }\end{array}$ & 1 & 1 & - & 1 & - & - & $\begin{array}{c}7 \\
11 \mathrm{~L}\end{array}$ & - & No & $\begin{array}{l}\text { Mild sedation } \\
\text { Hydroxyzine }\end{array}$ & No & 87 & 22 & $\begin{array}{c}76 \\
\mathrm{O}_{2}: 31 / \mathrm{min}\end{array}$ & 30 \\
\hline $\begin{array}{c}\text { Patient } 6 \\
\text { M/58 }\end{array}$ & $\begin{array}{l}\text { ET-MV/FiO } \mathbf{O}_{2}: \mathbf{0 . 4} \\
\text { VT: } 450 \mathrm{ml} \\
\text { PEEP: } 5 \mathrm{cmH}_{2} \mathrm{O}\end{array}$ & 1 & 2 & - & 1 & 1 & - & $\begin{array}{c}4 \mathrm{R} \\
7\end{array}$ & $\begin{array}{l}5.1 \\
4.6\end{array}$ & Adrenaline & $\begin{array}{l}\text { General anesthesia } \\
\text { Propofol } \\
\text { Sufentanil }\end{array}$ & Yes & 155 & 26 & $\begin{array}{c}85 \\
\mathrm{FiO}_{2}: 0.4\end{array}$ & 40 \\
\hline $\begin{array}{c}\text { Patient } 7 \\
\mathrm{M} / 73\end{array}$ & $\begin{array}{l}\text { Nasal Oxygen } \\
41 / \mathrm{min} \\
\end{array}$ & 1 & 1 & - & 1 & - & - & $\begin{array}{c}4 R \\
10 R \\
\end{array}$ & - & No & $\begin{array}{l}\text { Mild sedation } \\
\text { Hydroxyzine }\end{array}$ & No & 74 & 24 & $\begin{array}{c}87 \\
\mathrm{O}_{2}: 41 / \min \\
\end{array}$ & 35 \\
\hline $\begin{array}{l}\text { Patient } 8 \\
\text { M/68 }\end{array}$ & $\begin{array}{l}\text { ET-MV/FiO } \mathbf{O}_{2}: \mathbf{0 . 3 5} \\
\text { VT: } 450 \mathrm{ml} \\
\text { PEEP: } 5 \mathrm{cmH}_{2} \mathrm{O}\end{array}$ & 1 & - & 1 & 1 & - & - & $4 \mathrm{R}$ & - & No & $\begin{array}{l}\text { General anesthesia } \\
\text { Midazolam } \\
\text { Sufentanil }\end{array}$ & No & 92 & 25 & $\begin{array}{c}81 \\
\mathrm{FiO}_{2}: 0.35\end{array}$ & 40 \\
\hline $\begin{array}{l}\text { Patient } 9 \\
\text { M/39 }\end{array}$ & $\begin{array}{l}\text { LM-MV } \\
\text { VT: } 400 \mathrm{ml} \\
\text { PEEP: } 5 \mathrm{cmH}_{2} \mathrm{O}\end{array}$ & - & - & 1 & - & - & - & $4 \mathrm{R}$ & - & No & $\begin{array}{l}\text { General anesthesia } \\
\text { - TCI } \\
\text { Propofol } \\
\text { Remifentanil }\end{array}$ & No & 103 & 24 & - & 35 \\
\hline
\end{tabular}

Abbreviations. EBUS-TBNA: endobronchial ultrasound-guided transbronchial needle aspiration; PA: platelet antiaggregant; BA: bronchial aspiration; BAL: bronchoalveolar lavage; PP: pleural puncture; BB: bronchial biopsy; TTB: CT-guided transthoracic biopsy; OTLB: open thorax lung biopsy; PET: positron emission tomography; SUVm: maximal standard uptake value; M: male; F: female; R: right; L: left; TCI: targetcontrolled infusion; Duration: duration of the procedure.

${ }^{\mathrm{a}}$ acetylsalicylic acid 
Figures of the online supplement

Figure 1. Imaging of EBUS lymph node identification and puncture

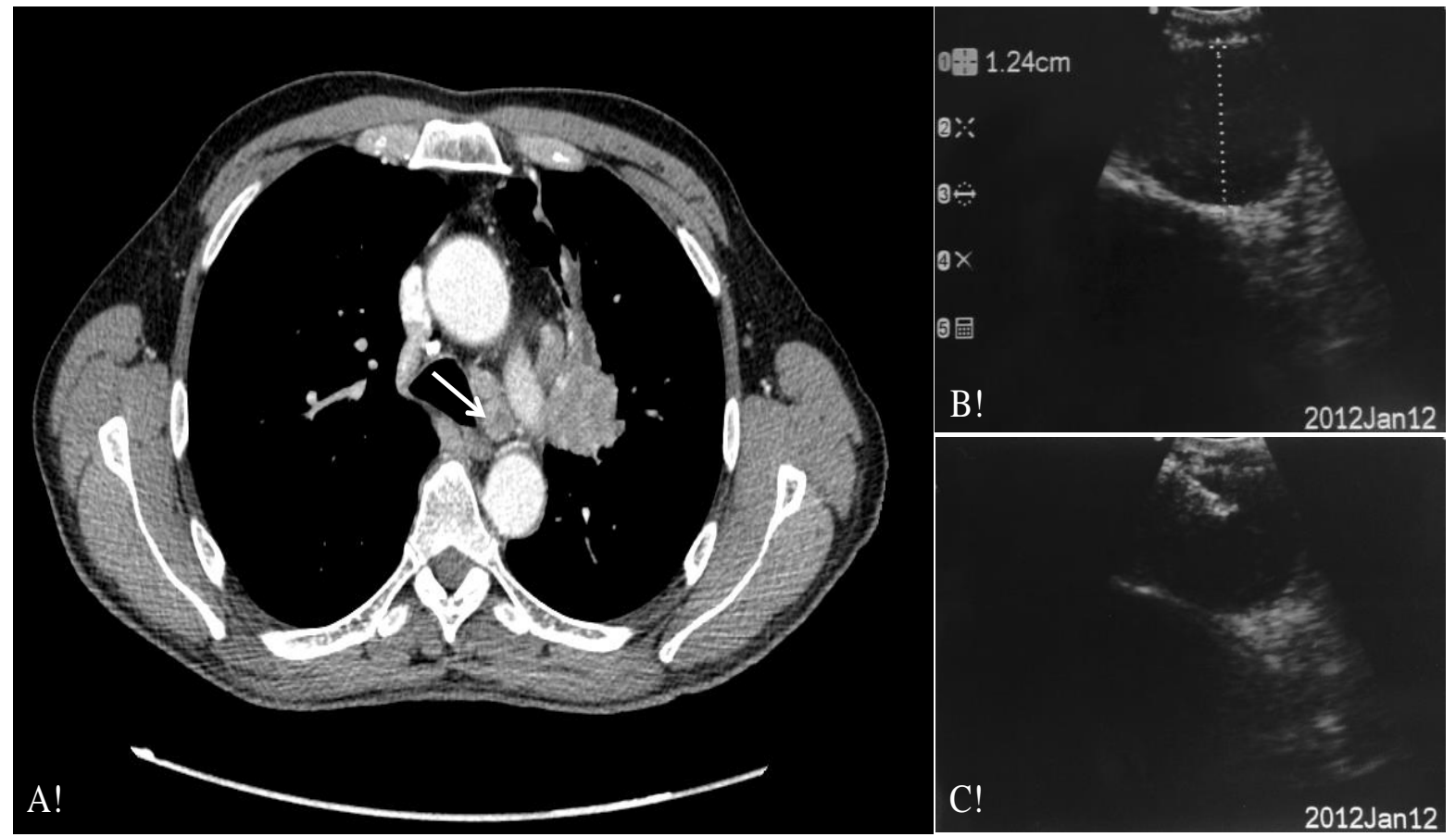

Arrow indicates the lymphadenopathy in station 4L (figure A), measuring 12mm with EBUS

(figure B). The figure (C) shows the real-time needle penetration into the lymph node.

EBUS: endobronchial ultra sound. 
Figure 2. Anatomical depiction of lymph node stations
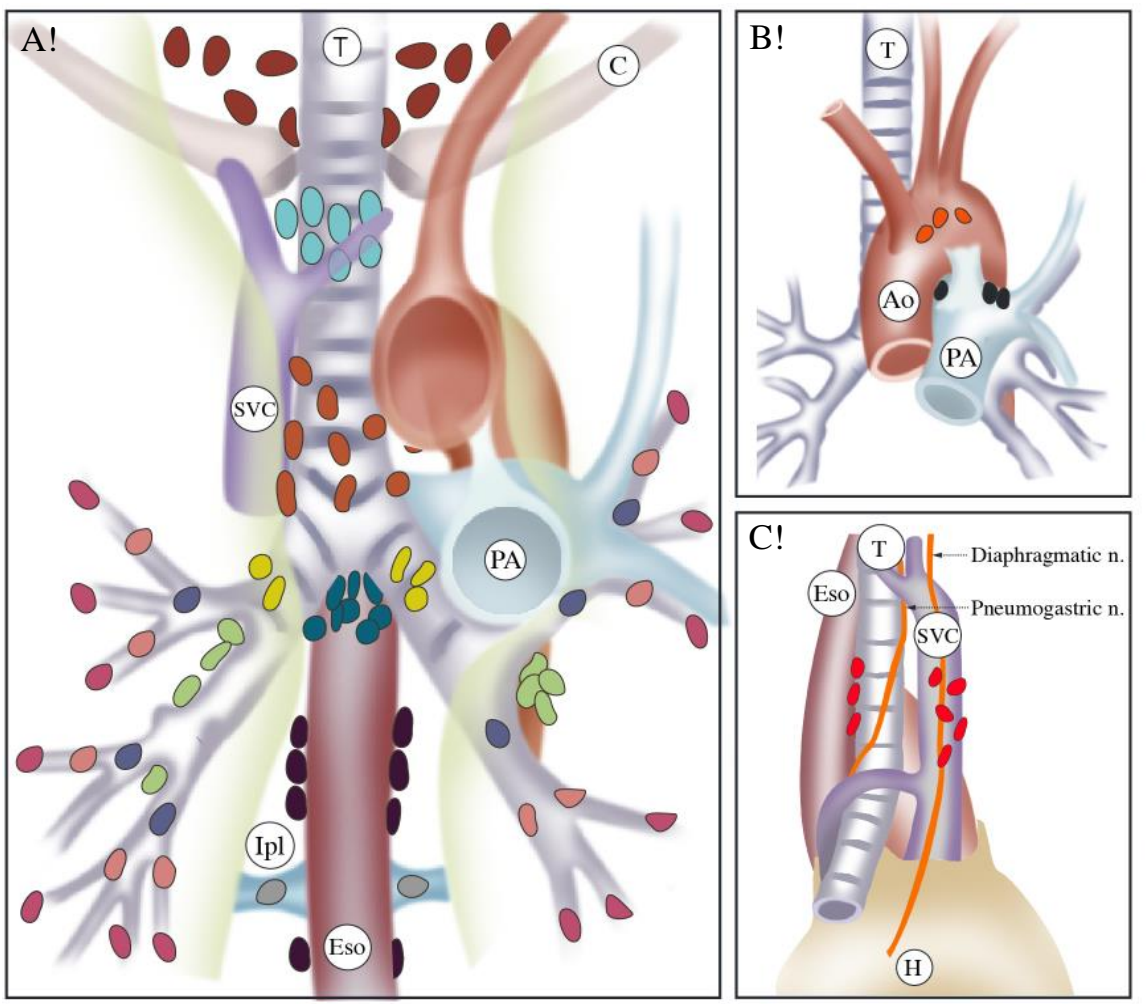
Superior Mediastinal Nodes
1 Highest Mediastinal 2 Upper Paratracheal
3 Pre-vascular and Retrotracheal
4 Lower Paratracheal (including Azygos Nodes)

Aortic Nodes

5 Subaortic (A-P window) 6 Para-aortic (ascending aorta or phrenic)

Inferior Mediastinal Nodes

7 Subcarinal

8 Paraesophageal

(below carina)

9 Pulmonary Ligament

Extra Mediastinal Nodes

10 Hilar
11 Interlobar
12 Lobar
13 Segmental
14 Subsegmental

Figure A, B and C represent respectively the anterior, posterior and right lateral view of the mediastinum. Stations 2, 3, 4, 710 and 11, 12, 13, are accessible with EBUS, as opposed to stations 5, 6, 8, 9 and 14. Adapted from references [36] and [37].

T: trachea; C: clavicle; SVC: superior vena cava; Ao: aorta; PA: pulmonary artery; Ipl: inferior pulmonary ligament, Eso: esophagus; H: heart; n.: nerve. 
